\title{
Accretion and Severed Mineral Estates
}

"See how this river comes me cranking in, And cuts me from the best of all my land ...."

William Shakespeare $\dagger$

The Yellowstone River runs through one of the richest oil fields in Montana. For nearly a century, developers have owned the minerals below the lands bordering the river, while the state claims the land beneath the river itself. ${ }^{1}$ In recent years there have been disputes over the ownership of these minerals among the developers, the state, and other property owners along the river. The problem is the shifting riverbed: since 1884, when the area was first surveyed, the river has narrowed and moved to the east. ${ }^{2}$ Vast quantities of oil and gas, originally located to the east of the river, now lie beneath the river itself, or to the west.

Under the ancient common law doctrine of accretion, title to property contiguous to a waterway such as the Yellowstone River changes in accordance with the river's movements. And although the law of accretion developed in the context of surface property rights, two recent state supreme courts have decided that the doctrine of accretion also applies to the severed ownership of minerals beneath the surface. ${ }^{3}$ The consequences of these rulings are substantial. In the Yellowstone River dispute, the original owners lost mineral estates of significant value. ${ }^{4}$ In other cases, accretion may force mineral lessees to drill additional wells to protect their leases, or may cause them to lose their leases altogether. The operators of mines or wells may become subject to suits for trespass and conversion, and production from those wells or mines could be inter-

$\dagger 1$ Henry IV, act 3, sc. 1, lines 97-98.

1 See Jackson v. Burlington N. Inc., 667 P.2d 406, 408 (Mont. 1983). The Yellowstone is considered a navigable river, thus giving the state title to the riverbed. Id. at 408.

${ }^{2}$ See id. at 407.

${ }^{3}$ See infra notes 16-29 and accompanying text.

4ee Jackson, 667 P.2d at 407. In 1905 there were only 1.81 acres of land west of the Yellowstone River in the section disputed in Jackson. By 1975 there were approximately 159 acres of land west of the river in the same section. Id. The dispute in Jackson was not so much over ownership of the 159 acres, but over ownership of the thousands of cubic acres of minerals beneath that land. 
rupted until the disputes are resolved.

This comment argues that the doctrine of accretion should not be applied to mineral estates that have been severed from surface estates. Rather, the subsurface boundary should be determined by survey when the mineral estate is severed, and that boundary should remain fixed regardless of any subsequent change in the surface boundary caused by shifting boundary waters. Part I of the comment provides a brief overview of the doctrine of accretion and discusses the cases that have applied the doctrine to severed mineral estates. Part II considers several possible barriers to the adoption of a fixed-boundary rule and assesses the relative merits of that rule and the doctrine of accretion.

\section{Accretion and Mineral Estates in the Courts}

The doctrine of accretion confers exclusive title on a landowner to lands gradually and imperceptibly added to his property by the movement of a river, lake, or sea. ${ }^{5}$ The doctrine of erosion takes from a landowner title to lands lost owing to the encroachment of such waters. ${ }^{6}$ The two doctrines are necessarily correlative,

s See, e.g., Arkansas v. Tennessee, 246 U.S. 158, 173 (1918); Missouri v. Nebraska, 196 U.S. 23, 34-36 (1904); Nebraska v. Iowa, 143 U.S. 359, 360-61 (1892); Jackson, 667 P.2d at 407. See generally 7 R. Powell \& P. Rohan, The Law of Reat Property II 983, at 607-11 (rev. ed. 1984) (defining accretion).

The doctrine of accretion can be traced to the Romans. See INST. Jusr. 2.1.20; INST. Gaius 2.70. Blackstone credited Bracton with adopting the Roman d natrine of alluvion into the English common law around 1260 A.D. 2 W. Blackstone, Commentaries *261-62; see also Bracton, 1 De Legibus et Consuetudinibus Angliae ch. 2, at 69-70 (T. Twiss ed. 1878) (1st ed. n.p. 1569); Recent Decisions, 24 CoLum. L. REv. 683, 683 (1924) (doctrine of alluvion "was taken bodily from the Roman law"). From those origins, the doctrine has taken root throughout the common law world. See, e.g., Nebraska v. Iowa, 143 U.S. 359, 360-61 (1892) (United States); Southern Centre of Theosophy Inc. v. South Australia, 1982 A.C. 706, 715 (P.C.) (Australia); Eliason v. Registrar, 115 D.L.R.3d 360, 362 (Alta. Q.B. 1980) (Canada); Penang v. Beng Hong Oon, 1972 A.C. 425 (P.C.) (Malaysia); Attorney-General of S. Nigeria v. John Holt \& Co., 1915 A.C. 599, 611-12 (P.C.) (Southern Nigeria).

Accretions are of two kinds: alluvion and reliction (or dereliction). Alluvion is land created by the deposit of silt and debris from a body of water. See, e.g., United States v. Claridge, 279 F. Supp. 87, 88-89 (D. Ariz. 1967), aff'd, 416 F.2d 933 (9th Cir. 1969), cert. denied, 397 U.S. 961 (1970). Reliction or dereliction is land added when a body of water withdraws or recedes, thereby leaving a portion of its bed dry. See, e.g., Fontenelle v. Omaha Tribe, 298 F. Supp. 855, 858 (D. Neb. 1969), aff'd, 430 F.2d 143 (8th Cir. 1970). See generally Note, Artificial Additions to Riparian Land: Extending the Doctrine of Accretion, 14 ARIz. L. REv. 315, 321-24 (1972) (discussing kinds of accretion). Technically, accretion refers to the process or act by which alluvions and relictions are created, and not to the alluvions or relictions themselves. However, the term is often used as a noun synonymous with alluvion and reliction. See Black's Law Dictionary 19, 70, 1161 (5th ed. 1979).

- Jackson, 667 P.2d at 407; see also Oklahoma v. Texas, 268 U.S. 252, 256 (1925). Erosion is the gradual eating away of the soil by currents or tides. BLAck's Law Dictionary 486 
since to apply one without the other would result in dual ownership of property. The term accretion thus may be used to refer to the combined effect of both doctrines. ${ }^{7}$

When a river is not navigable, the boundary between the estates on either side is typically set at the river's center line. ${ }^{8}$ The doctrine of accretion maintains the boundary at that line even as the river moves, although the acreage of one estate may increase and that of the other may decrease. ${ }^{9}$ When the river is navigable, the state will often hold title to the riverbed. ${ }^{10}$ Privately owned riparian estates will then extend to either the high-water mark or the low-water mark on each side of the river, depending on the law of the jurisdiction. ${ }^{11}$ In that situation, the doctrine of accretion op-

(5th ed. 1979).

? The doctrine of avulsion, not accretion, applies when a change in a river's course is sudden and perceptible. Under the doctrine of avulsion, a sudden change in the course of a riverbed does not affect the boundaries of riparian land. See, e.g., Nebraska v. Iowa, 143 U.S. 359,361 (1892).

It can be difficult to determine whether a shift in a river is accretive or avulsive. The Roman jurist Gaius required the change to be so slow ut oculos nostros fallat (as to fail our sight). INST. GaIUS 2.70. Justinian's code of laws said the process must be so slow ut intelligere non possis, quantum quoque momento temporis adiciatur (as knowledge is not had how much is added in a moment). INST. JUST. 2.1.20. In a famous case, Chief Justice Abbott noted that an extremely minute accretion "may become, by gradual increase, perceptible ... at the end of a century, or even forty or fifty years," and suggested that an accretive shift must be "imperceptible in its progress, not imperceptible after a long lapse of time." King v. Lord Yarborough, 3 B. \& C. 91, 106-07, 107 Eng. Rep. 668, 674 (K.B. 1824), aff'd, 2 Bligh N.S. 147, 1 Dow. \& Cl. 178, 4 Eng. Rep. 1087 (H.L. 1828); see also County of St. Clair v. Lovingston, 90 U.S. 46, 68 (1874) (a shift is accretive when, although "witnesses may see from time to time that progress has been made, they could not perceive it while the progress was going on"); Jackson, Alluvio and the Common Law, 99 L.Q. REv. 412, 421-24 (1983).

If actual perceptibility at the moment of accretion is the test, then the ability of the human eye to detect movement may be the deciding factor. At the distance of five feet (eye level for one standing on the bank of a river), a movement of one inch per minute is just under the limit of perceptibility. See Scott \& Stevenson, Shore Accretions from the Geographical Standpoint, 10 Mich. ST. B.J. 215, 228 (1931). Such a movement would produce an accretion of 120 feet per day, or more than eight miles per year! Scott and Stevenson note that the fastest reported accretion on a seashore grew at the rate of only 200 feet per year. Id. at 229.

' See, e.g., City of Missoula v. Bakke, 121 Mont. 534, 539, 198 P.2d 769, 772 (1948); Anderson-Prichard Oil Corp. v. Key Okla. Oil Co., 149 Okla. 262, 265, 299 P. 850, 852 (1931).

${ }^{8}$ See Nebraska v. Iowa, 143 U.S. 359, 361 (1892) (referring to rivers which form the boundary between two states or nations, the Court observed that "[a]ccretion, no matter to which side it adds ground, leaves the boundary still the centre of the channel"). Quite a different result would be reached under the doctrine of avulsion. If the river's movement was avulsive, the boundary would remain fixed where it was when the avulsive shift took place: at the center line of the former riverbed. Id. Thus, if the river shifted far an owner on the bank of the old riverbed could lose all access to the river.

${ }^{10}$ See infra note 67 and accompanying text.

11 See, e.g., Jackson, 667 P.2d at 409 (low-water mark); Gibson v. Kelly, 15 Mont. 417, 
erates to maintain the boundaries at the appropriate water-level mark as the river moves.

At least four rationales have been offered in support of the doctrine of accretion. ${ }^{12}$ First, the doctrine ensures that owners of land bounded by water will continue to enjoy their riparian rights and access to water even if the boundary water shifts. Second, the doctrine awards accretions to the owners of the abutting land, who are better situated than landowners on the opposing bank to use the land productively. Third, the doctrine appears to be evenhanded: although it imposes a risk of loss, it also bestows a potential for gain. Finally, the doctrine is thought to be fairly easy for courts and laymen to apply. ${ }^{13}$

In addition to altering the boundaries of property on the surface, the doctrine of accretion can also affect boundaries above and below the surface. Under the traditional doctrine of property ownership ad coelum, the surface owner controls not only the surface, but also everything "to the sky and to the depths."14 Thus, when the property above, on, and below the surface is held by a single owner, it makes intuitive sense for an accretive shift in the surface boundary also to shift the boundary above and below the surface. In such a case, not only are the surface benefits of accretion obtained, but the boundary of the property above and below the surface remains unified and identifiable.

However, when the surface and subsurface portions of a piece of property are not held by a single owner-if the mineral estate has been severed from the surface by conveyance of legal title or

420-22, 39 P. 517, 519 (1895) (observing that some jurisdictions use the high-water mark while others use the low-water mark).

12 See, e.g., Beck, The Wandering Missouri River: A Study in Accretion Law, 43 N.D.L. Rev. 429, 431-39 (1967); Note, supra note 5, at 322-24; Recent Decisions, supra note 5, at 683; Comments on Recent Cases, Real Property-Navigable River-Accretion to Riparian Land, 45 Iowa L. Rev. 945, 948-50 (1960). These rationales are discussed infra at notes 34-66 and accompanying text.

13 At least two other less powerful rationales for accretion have been suggested. One is "an analogy to accession. When a cow produces a calf, generally the calf belongs to the owner of the cow .... So too to the early more formalistic mind accretion was the creation of new land and it ought to belong to the owner of the land to which it was added." Beck, supra note 12 , at 432 .

Another rationale is the notion that accretion involves small amounts of land that are "too little to worry about either by a court or someone other than the riparian owner." Id. at 433-34. While that de minimus rationale may be valid in some cases, it does not support the application of the doctrine in cases where significant amounts of land are involved. $I d$.

14 Jackson Mun. Airport Auth. v. Wright, 232 So. 2d 709, 711 (Miss. 1970) (noting that state and federal authorities "have long since substantially modified that concept"). 
lease to another party ${ }^{15}$ - then it is not clear that the doctrine of accretion should apply to the boundaries of both the surface and subsurface estates. Because the traditional rationales for the accretion rule relate primarily to the interests of the surface owner, there is some question whether the boundaries of a severed mineral estate should shift according to accretion on the surface or remain fixed regardless of surface boundary changes.

Only two courts have considered this question. ${ }^{16}$ Both courts concluded that the ownership of severed estates should shift in accordance with accretive changes in the corresponding surface estates. The first case, Nilsen $v$. Tenneco Oil Co., ${ }^{17}$ addressed the issue in the context of a non-navigable river. In rejecting a fixedboundary rule, the Supreme Court of Oklahoma based its reasoning in part on the axiom that a grantor may not convey an estate greater than that which he possesses. Because an unsevered estate is subject to loss by erosion, the court explained, it follows from the axiom that the owner of an unsevered estate may not convey a severed mineral estate that is not subject to loss by erosion. ${ }^{18}$

The court also claimed that applying a fixed-boundary rule would result in "gross inequities" when an unsevered estate is bor-

15 The owner of an unsevered estate in fee owns the surface of the land as well as any minerals beneath it. There are two ways in which a severed mineral estate can be created from an unsevered estate. The owner of a unsevered estate may convey an interest in the minerals, retaining an interest in the surface, or may convey an interest in the surface, while retaining an interest in the minerals. Either transaction creates a severed mineral estate in fee that is independent of the overlying surface estate. See Richard Hemingway, The Law of OIL and GaS § 1.3, at 27 (1983); H. Whliams \& C. Meyers, OIl and Gas Law $\$ 202.2$ (abridged ed. 1973). For a discussion of the principles used to identify the boundaries between surface estates and severed mineral estates, see infra note 40 .

For the purposes of this comment, a lease of the mineral estate is equivalent to a conveyance of the minerals. This is true because a mineral lease, unlike other types of leases, is tantamount to ownership. A mineral lessee typically has the exclusive right to remove the minerals specified in the lease, and receives full title to the minerals it extracts. It exercises absolute control over the mineral estate, subject only to contractual obligations in the lease document. Because the lease typically lasts as long as minerals are produced in significant quantities, at its termination the owner receives only a depleted estate. The leasehold therefore typically represents a substantial portion, if not the full value of the fee and may deserve legal treatment resembling that of a deed. See generally $\mathrm{H}$. Williams \& C. MEYERs, supra, $\S \S 202.1,207$ (discussing legal character of mineral leases).

Whether or not a mineral estate has been severed, the owner of the minerals commonly does not participate directly in the development of the oil and gas reserves. R. HEMINGWAY, supra, $\S 2.1$, at $33-34$. Instead, he usually receives a royalty, which is a share of the production or the proceeds of its sale. The owner may in addition receive a cash consideration. See H. Williams \& C. Meyers, supra, § 202.1.

${ }^{18}$ See Jackson, 667 P.2d at 408; id. at 410 (Davis, J., dissenting).

17614 P.2d 36 (Okla. 1980).

${ }^{18}$ Id. at 41-42. 
dered by a severed mineral estate. ${ }^{19}$ According to the court, under a fixed-boundary rule the severed estate would not be subject to loss by erosion, and therefore the unsevered estate could never gain by accretion. However, the court also asserted that the reverse was not true: the unsevered estate would be subject to loss by erosion, and therefore the severed estate could gain by accretion. The court argued that such a one-sided result was unfair, and would be avoided by adopting the doctrine of accretion. ${ }^{20}$

Lastly, the court defended its decision by noting that the owner of a severed mineral estate would have an implied easement to go onto the surface and "take measures" to protect against erosion, "given the proper circumstances." scribe what those circumstances would be, nor did it explain what kinds of measures would be appropriate. ${ }^{22}$

In Jackson v. Burlington Northern Inc. ${ }^{23}$ the Supreme Court of Montana agreed with the result in Nilsen and applied the doctrine of accretion to subsurface estates bordering the Yellowstone River, a navigable waterway. The Montana court added three reasons for applying the doctrine of accretion to severed mineral estates. First, it observed that a fixed-boundary rule would result in discrepancies between the surface and subsurface portions of unsevered estates bordering severed mineral estates. ${ }^{24}$ Those discrepancies would not be evident from examination of a chain-of-title record for the unsevered estate; a purchaser relying solely on that record could incorrectly conclude that his subsurface holdings were as extensive as his surface holdings. ${ }^{25}$

10 Id. at 42.

${ }^{20}$ Id. The court's concern was unfounded, since it was based on an incorrect understanding of how a fixed-boundary rule would operate. See infra notes 55-59 and accompanying text.

${ }^{21}$ Nilsen, 614 P.2d at $42-43$. The court noted that the easement would not be implied if the instrument which created the severed estate specifically prohibited it. Id. at 43.

22 The court also rejected an analogy to adverse possession found persuasive by the trial court. Adverse possession of all or part of a surface estate has no effect on the title to a severed mineral estate, unless the adverse possessor interferes with the mineral estate by mining or drilling. See, e.g., Deruy v. Noah, 199 Okla. 230, 232-33, 185 P.2d 189, 191 (1947). In the trial court's view, the adverse possession rule indicated that mineral and surface estates are separate and independent after title to the minerals is severed. Therefore, it reasoned that changes in the surface estate, whether by adverse possession or accretion, should not affect the mineral estate. Nilsen, 614 P.2d at 40-41. Reversing the trial court, the Supreme Court of Oklahoma insisted that the law of adverse possession has no relevance to the problem of accretion. Id. at 41 ("[A]dverse possession cases [are] statute of limitations cases, not property right cases.").

${ }^{23} 667$ P.2d 406 (Mont. 1983).

24 Id. at 409.

${ }^{25}$ Id. 
To illustrate, suppose $A$ holds an unsevered estate on the east bank of a river, and $B$ holds a severed mineral estate on the west bank. Suppose also that the river moves westward, toward the severed estate. Land could not accrete to the subsurface portion of $A$ 's estate because the western edge is the fixed boundary of a severed mineral estate, which would not be subject to erosion. However, land could accrete to the surface portion of $A$ 's estate, because the surface estate above $B$ 's mineral estate remains subject to erosion. Eventually, the surface portion of $A$ 's estate would extend far westward of the subsurface portion, even though $A$ has never severed the estates (see figure 1).

Figure 1: Shift of a Non-Navigable Waterway

Before:

\begin{tabular}{|c|c|}
\hline \multicolumn{2}{|c|}{ Riverbed } \\
\hline & \\
\hline $\begin{array}{l}\text { B's surface } \\
\text { estate }\end{array}$ & $\begin{array}{l}\text { A's surface } \\
\text { estate }\end{array}$ \\
\hline $\begin{array}{l}\text { severed } \\
\text { mineral } \\
\text { estate }\end{array}$ & $\begin{array}{l}\text { A's mineral } \\
\text { estate } \\
\text { (unsevered) }\end{array}$ \\
\hline
\end{tabular}

After:

New

Old

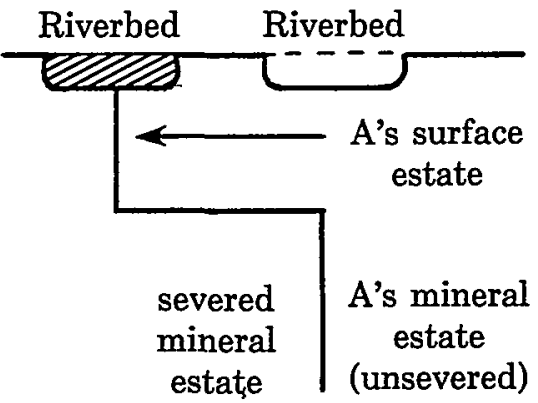

Second, the court observed that if severed mineral estates were not subject to accretion, the state could be divested of its subsurface lands under navigable rivers. ${ }^{26}$ To illustrate, suppose a navigable river flows from north to south between an unsevered estate on the east bank and a severed estate on the west bank. Suppose also that the river is slowly shifting westward. If the state has not severed its mineral rights below the riverbed, the doctrine of accretion would apply to the boundary between the state's holdings and the eastern unsevered estate, while a fixed-boundary rule would apply to the boundary between the state's holdings and the estate to the west. As the river moves westward, the surface portion of the state's holdings advances with it, since surface estates continue to be governed by the doctrine of accretion. However, be- 
cause the subsurface portion of the state's holdings borders a severed estate, its boundary remains fixed and does not advance with the river. Meanwhile, the unsevered estate to the east advances westward with the river, gaining land above and below the surface under the doctrine of accretion. Thus, the state's subsurface holdings are reduced as the river shifts to the west, since its eastern boundary would be contracting while the western boundary would remain fixed. Indeed, the state's subsurface holdings could be squeezed out entirely if the east bank of the river advances past the original location of the river's west bank. The court argued that this result would be "clearly contrary" to a state statute that gives the state title to lands under navigable rivers. ${ }^{27}$

Finally, the court argued that the boundaries of severed mineral estates would be difficult to determine if they were not subject to the doctrine of accretion. ${ }^{28}$ The court observed that the efficacy of a fixed-boundary rule depends on whether a survey was conducted at the time of severance. If not, the movement of the river would make it difficult to establish where the boundary was located when the estate was severed. The court surmised that the problem had arisen in the case before it, and added that "other owners of severed mineral estates might have like difficulties locating surveys which correspond with pertinent severance dates."29

\section{Choosing A RULE}

The courts' decisions in Nilsen and Jackson identified some of the problems that might arise if a fixed-boundary rule applies to severed mineral estates, but failed to identify the problems that arise if the doctrine of accretion applies. To assess properly whether the doctrine of accretion should apply to severed mineral estates, courts must consider three questions. First, does adoption of a fixed-boundary rule violate traditional rules governing conveyance of property? Second, which rule best promotes the policies that the doctrine of accretion traditionally serves? And third, does a fixed-boundary rule conflict with state ownership of land beneath navigable rivers?

${ }^{27}$ Id.; see MONT. CODE ANN. $\$ 70-1-202(1)$ (1985). For an illustration of how state ownership is affected by movements in navigable waterways under a fixed-boundary rule, see figure 2 infra at text following note 71; see also infra notes 67-80 and accompanying text (discussing state ownership of riverbeds).

${ }^{23}$ Jackson, 667 P.2d at 409.

20 Id. 


\section{A. The Axiom}

The Nilsen court argued that a fixed-boundary rule would violate the "axiomatic principle of law that a grantor cannot convey an estate greater than that possessed by him": ${ }^{30}$ since the original unsevered estate is subject to loss by erosion and the severed mineral estate would not be subject to loss by erosion, the owner of the severed estate would have received a greater estate than the owner of the unsevered estate possessed. ${ }^{31}$

This argument misconstrues the purposes of the axiom. Historically, the axiom has been directed at the conveyance of estates of greater legal dignity, such as when the owner of a life estate attempts to convey a fee simple, or when the owner of a defeasible fee attempts to convey an indefeasible fee. ${ }^{32}$ In those cases the axiom implements important policies: it protects the original grantor's intent to convey a limited estate and protects holders of remainders, reversions, or other interests in the same property. However, the axiom has not been applied when opposing policy concerns are sufficiently implicated. For example, courts have promoted the alienability of property by allowing the conversion of a fee tail into a fee simple either by conveyance or by common recovery and fine. ${ }^{33}$ Barring the entail in this manner destroys a reversionary interest, which is a far greater interest than the possibility of gain or loss by accretion. This comparison suggests that the axiom alone is insufficient to preserve the accretion rule for severed mineral estates.

Thus, the argument that the axiom presents an outright bar to a fixed-boundary rule rests on a mistaken understanding of the nature of common law rules governing transfers of property. Like

so Nilsen, 614 P.2d at 41.

s1 It should be noted that the original owner and the owner of the severed mineral estate could be the same person. Such a situation would arise in cases where the severed estate was created when the owner of an unsevered estate conveys the surface estate to another party while retaining the subsurface minerals. See supra note 15 . In such cases there would have been no conveyance of the minerals, and thus technically the axiom would seem to be inapplicable. However, the Nilsen court implicitly rejected that distinction. See 614 P.2d at 37.

${ }^{32}$ See, e.g., Lovett v. Stone, 239 N.C. 206, 214, 79 S.E. 2d 479, 485 (1954) (grantor who held a life estate cannot convey an estate in fee); Riner v. Fallis, $176 \mathrm{Ky} .575,578,195 \mathrm{~S} . \mathrm{W}$. 1102,1103 (1917) (owner of a defeasible fee cannot convey a fee absolute); 2 R. PowELL \& P. Rohan, supra note 5, II 190[2]; Restatement of Property § 50 (1936).

${ }^{3 s}$ See, e.g., Mildmay's Case, 6 Coke Rep. 40a, 41a, 77 Eng. Rep. 311, 314 (K.B. 1607) ("[I]f a man makes a gift in tail, on condition, that he shall not suffer a common recovery . . this condition is repugnant to the estate-tail and against law."). For a brief history of the methods of barring entails, see Herbert Tiffany, Law of Real Property $§ 51$ (1940). 
those other rules, the axiom is not an irrefutable principle of logic with universal applicability, but is a convenient justification for results that are desirable from a policy perspective. It therefore begs the question simply to state mechanically that a fixed-boundary rule violates the axiom; it is necessary to examine policy considerations in order to determine whether the axiom should apply to the creation of subsurface estates with fixed boundaries.

\section{B. Policy Considerations Favoring a Fixed-Boundary Rule}

To some degree the Nilsen and Jackson decisions sketch out the policies that underlie the doctrine of accretion. The courts have advanced four key arguments in support of applying a rule of accretion on the surface: (1) the importance of presorving riparian landowners' access to water; (2) the desirability of awarding accretions to the party who will use them most productively; (3) the possibility that the potential for gaining land will offset the risk of losing it; and (4) the ease with which the doctrine can be applied. ${ }^{34}$ While these arguments may justify a rule of accretion for surface boundaries, they would be equally or better served by applying a fixed-boundary rule to subsurface estates.

1. Access to Water. The most important purpose of the doctrine of accretion is to ensure that riparian landowners will enjoy continued access to water even if the river shifts away from their land..$^{35}$ In contrast, under a fixed-boundary rule riparian owners could lose their access to water as the river shifts, since eventually a sliver of property could emerge between the river and the fixed boundary of their land. ${ }^{36}$ The significance courts attach to contin-

36 See supra note 12 and accompanying text.

35 This feature of the doctrine of accretion has long been regarded by many courts and commentators as its most compelling virtue. See, e.g., Lamprey v. State, 52 Minn. 181, 19798,53 N.W. 1139, 1142-43 (1893) ("But it seems to us that the rule rests upon a much broader principle, and has a much more important purpose in view, viz. to preserve the fundamental riparian right-on which all others depend, and which often constitutes the principle value of the land-of access to water.") (emphasis in original); 7 R. PowELL \& P. RoHAN, supra note 5, II 983, at 610 " "The basic justification for [the] doctrine . . . is the desirability of keeping land riparian . . . thus assuring the upland owners access to the water and the advantages of this contiguity."); Beck, supra note 12, at 436-38; see also Sieck v. Godsey, 254 Iowa 624, 627, 118 N.W.2d 555, 557 (1962) ("The theory of accretion is that it permits a riparian owner to continue his access to the shore or water line."). But cf. Comments on Recent Cases, supra note 12, at 949 (when a considerable amount of alluvial land is involved, a more equitable solution might be "to grant [a] right-of-way over the alluvial land for the purpose of maintaining the access to the river").

${ }^{36}$ See Lamprey v. State, 52 Minn. 181, 197, 53 N.W. 1139, 1142 (1893) (court discusses the "incalculable mischiefs that would follow if a riparian owner is liable to be cut off from access to the water, and another owner sandwiched in between him and it"). 
ued access to water is reflected in the way they partition accretions among riparian owners: courts maintain each owner's original proportionate share of river frontage, even if that requires altering the relative distribution of acreage. ${ }^{37}$

When viewed in this light, the application of the accretion doctrine to changes in riparian boundaries can be seen as an attempt to minimize collective risks to land owners. Under the rule of accretion, a riparian owner is assured of continued access to water, but runs the risk of losing land; under a fixed-boundary rule, the owner will not lose land, but runs the risk of losing access to water. ${ }^{38}$ Since access to water for agricultural, commercial, and domestic uses is often the "most valuable feature" of riparian land, ${ }^{39}$ riparian owners are collectively better off under the doctrine of accretion, which maximizes the value of their land by minimizing the risk of losing its most important component. In effect, courts invoking the "access to water" rationale choose the doctrine of accretion because it allocates the risks associated with the movement of bodies of water so as to minimize the injustice inflicted on riparian owners as a whole.

This rationale shows the accretion rule to be compelling as applied to surface boundaries, but it undermines the rule as applied to severed mineral estates. Most severed mineral estates are located too far below the surface to be contiguous to rivers or lakes, and thus do not enjoy the benefits associated with contiguity. ${ }^{40}$ If

${ }^{37}$ See, e.g., Jennings v. Shipp, 115 N.W.2d 12, 15 (N.D. 1962); Beck, supra note 12, at 438-39.

ss However, some or all of the land could be submerged.

${ }^{39}$ Bonelli Cattle Co. v. Arizona, 414 U.S. 313, 326 (1973), overruled on other grounds, Oregon ex rel. State Land Bd. v. Corvallis Sand \& Gravel Co., 429 U.S. 363, 381 (1977).

${ }^{10}$ The clearest example is an estate of minerals in stratum. In such an estate, a person has rights to minerals only at certain depths or in certain geological formations. See, e.g., Barnes v. Mack Oil Co., 376 P.2d 279, 280 (Okla. 1962) (court cancelled lease down to approximately 10,800 feet below the surface, but preserved it below that depth). For example, one party may own coal in a field between 450 and 700 feet below the surface, another party may own the coal in the field between 700 and 1000 feet below the surface, and yet another party may own the oil and gas at depths below 2000 feet. Surface rivers typically will be hundreds of feet above the estates in coal.

Mineral estates not in stratum are also typically not contiguous to bodies of water on the surface. There is no clear boundary line between surface and subsurface estates, but courts have drawn a rough line of division. Generally, a severed mineral estate does not include minerals that must be removed by methods, such as strip mining or open pit mining, that would leave "the utility of the surface for agricultural or grazing purposes . . . destroyed or substantially impaired." Acker v. Guinn, 464 S.W.2d 348, 352 (Tex. 1971). Alternatively, some courts hold that any substance within 200 feet of the surface is a "near surface" substance and therefore pertains to the surface estate. See Reed v. Wylie, 597 S.W.2d 743, 748 (Tex. 1980); Reed v. Wylie, 554 S.W.2d 169, 172 (Tex. 1977). Under either 
severed mineral estates do have any rights to surface water, it is because those rights were expressly reserved or conveyed. ${ }^{41}$ In short, direct access to water, an important asset to the surface owner, is unimportant to the owner of the mineral estate. Below the surface, the key factor is continued access to and control over the minerals themselves-a factor which is only marginally affected by changes in the location of boundary waters on the surface.

In fact, the most important principle behind the "access to water" rationale-minimization of collective risk to owners by preserving the most important component of the riparian estate's value-militates against the doctrine of accretion for severed mineral estates. The choice is between the doctrine of accretion, under which the owner of a severed mineral estate can either gain or lose land, and a fixed-boundary rule, under which the owner's holdings remain constant. From the standpoint of providing incentives to develop minerals - the primary purpose of severing a mineral estate-the second alternative is better.

This is so because the existence of fixed boundaries for subsurface mineral estates helps to promote the development and exploitation of mineral resources. Under a regime of accretion, shifts in the surface boundary transfer wealth between subsurface owners without any relation to either owner's ability to recover or develop the minerals. The uncertain nature of those transfers increases the risks involved in developing minerals beneath riparian lands without also increasing the expected returns from development, thus on the whole discouraging mineral development. In contrast, when boundaries are fixed, the value of a subsurface mineral deposit will be more easily ascertainable because it is not subject to arbitrary change. In the long run, this greater certainty and stability encourages investment in mineral development.

In addition, a fixed-boundary rule may reduce or eliminate other conflicts or costs existing under a rule of accretion. For example, oil and gas leases usually last for a term of years and "as long thereafter as oil or gas .... is produced from [the] land by

approach, severed mineral estates will begin at sufficient depths that they are not likely to be contiguous to a body of water on the surface.

11 Water, unless severed expressly by conveyance or reservation, belongs to the surface estate. Fleming Found. v. Texaco, Inc., 337 S.W.2d 846, 850 (Tex. Civ. App. 1960). Some courts have granted to mineral lessees an implied right to use reasonable amounts of underground water for the development and production of minerals. See, e.g., Sun Oil Co. v. Whitaker, 483 S.W.2d 808, 810 (Tex. 1972); Mack Oil Co. v. Laurence, 389 P.2d 955, 961-62 (Okla. 1964). 
[the] lessee."42 One producing well may preserve the lease on hundreds or thousands of acres. If the well is located on land that is eroded away from the mineral estate, the lease on the entire property may terminate.

Even if the lessee preserves the lease through production from other wells on the property, he may incur additional expenses because of an offset well covenant in the lease. An offset well covenant requires a lessee to drill wells to offset drainage from the property by wells on adjoining lands. ${ }^{43}$ Where a well once on the leasehold is lost because of the doctrine of accretion, the lessee may be obligated to drill a new well to offset production from the well he had drilled earlier. Failure to do so may make him liable in damages to the lessor or may terminate the lease for the whole property-including its other producing wells.

To summarize, the doctrine of accretion as applied to surface lands protects a valuable asset of ownership-access to water-and thus tends to minimize the losses that the movement of rivers inflicts on neighboring landowners. However, as applied to subsurface boundaries, accretion has precisely the opposite effect: it makes landowners and other participants in the mineral extraction business worse off than they would be under a fixed-boundary rule.

One could argue that the problems associated with an accretion rule can be overcome if the parties negotiate contractual solutions that reduce or eliminate the risks ex ante; modify their behavior to avoid the risks, even though their modified behavior might be less productive than the path they would otherwise follow; or ignore the risks and litigate to protect their position if conflicts arise. But each of these strategies would itself involve costs-costs that would not be imposed by a fixed-boundary rule.

2. Productivity. Another common rationale for applying the doctrine of accretion to changes in surface boundaries is that it awards accretions to the party that can most productively use them. ${ }^{44}$ Early common law authorities recognized that a fixedboundary rule for surface estates could leave landowners with narrow slivers of property between the river's old and new shores. Al-

12 Baldwin v. Blue Stem Oil Co., 106 Kan. 848, 849, 189 P. 920, 921 (1920); see also H. Williams \& C. MeYers, supra note $15, \S 202.1$.

t3 See R. Hemingway, supra note 15, §§ 8.5, 8.6; see also Gerson v. Anderson-Prichard Prod. Corp., 149 F.2d 444, 446 (10th Cir. 1945).

14 See, e.g., Beck, supra note 12, at 434-35; Note, supra note 5, at 323 \& n.46; see also Jefferis v. East Omaha Land Co., 134 U.S. 178, 191 (1890) ("it is the interest of the community that all lands should have an owner, and most convenient that insensible additions to the shore should follow the title to the shore"). 
though they might grow larger with further movements, small strips of land were thought to be of little use to the original holder. By shifting the neighbor's boundary in accordance with the river's movements, the doctrine of accretion grants the narrow strip to the most productive user-the owner of the contiguous estate. ${ }^{45}$

This rationale is largely inapplicable to severed mineral estates. Barring unusually difficult terrain, small changes in the surface boundary create no inaccessible or unproductive slivers of subsurface property. Rather, with modern slant drilling or mining technology, the owner of a mineral estate still can reach and remove the minerals even if the shifting riverbed impedes direct access to the subsurface estate. ${ }^{46}$

Moreover, the holder of a severed mineral estate is likely to be the most productive user of the subsurface rights. There is little incentive to retain or purchase a subsurface estate except to develop its minerals. Thus, the holder of the severed estate often will have already begun to formulate plans and invest in measures specifically aimed at developing these subsurface minerals.

The accretion doctrine poses a threat to the severed mineral estate-and thus to the party that is often the most productive user-because changes in the surface boundary could make the subsurface holder into a trespasser both above and below the surface. The extraction of subsurface minerals requires the construction of a variety of fixtures, such as wells or mine shafts, that may be located on and below the surface. If title to the land in which those fixtures are located changes hands with a shift in surface wa- ters, the party that is currently developing the subsurface minerals could become liable to the new owners of the land for trespass and conversion. ${ }^{47}$ Inadvertent trespasses could occur even where wells are not located on the surface of the accreted property; if wells are drilled at an angle, the subsurface boundary could shift across the lower portions of the wells, giving rise to a claim of trespass against

15 See, e.g., The King v. Lord Yarborough, 2 Bligh N.S. 147, 1 Dow. \& Cl. 178, 4 Eng Rep. 1087 (H.L. 1828) (Best, C.J., delivering the advice of the judges to the House of Lords).

16 An owner of a mineral estate typically gains access through the surface estate ut the grantor. Cf. Kemmerer v. Midland Oil \& Drilling Co., 229 F. 872, 875 (8th Cir. 1915) (grant of a right in subsurface implies right of access).

17 See H. Williams \& C. MeYers, supra note 15, §§ 225-27; Swiss Oil Corp. v. Hupp, $253 \mathrm{Ky} .552,555,69$ S.W.2d 1037, 1039 (1934) (inadvertent trespasser liable for damages and may take no profit from operations); Champlin Refining Co. v. Aladdin Petroleum Corp., 205 Okla. 524, 525, 238 P.2d 827, 828 (1951) (accounting for conversion of oil and gas); cf. Phillips Petroleum Co. v. Cowden, 241 F.2d 586, 592 (5th Cir. 1957) (suit in assumpsit for reasonable value of use and occupation when defendants performed unauthorized seismological tests on mineral estate). 
some part of the fixtures. ${ }^{48}$ If oil and gas are produced from the well after it comes to be bottomed on adjoining property, the mineral owner may be liable for the full value of all oil produced.49

A fixed-boundary rule applied to severed mineral estates protects the holder of the subsurface estate against this threat by not allowing the boundary to move and transform a subsurface fixture into a trespass. ${ }^{50}$ Avoiding this risk could result in significant savings. Lawsuits would involve complicated legal and factual issues, such as when the trespass first occurred and what should be done with the trespassing fixtures. The money spent to resolve those issues is money the parties would not have to spend under a fixedboundary rule. In addition, the risk of suit itself may deter developers from installing fixtures at locations that might otherwise be optimal. $^{51}$

${ }^{48}$ For example, assume a case in which $A$ and $B$ are neighboring landowners, and $A$ has drilled a well at an angle so that the bottom of the well is located several hundred feet closer to $B$ 's land than is the surface perforation. Under the doctrine of accretion, the boundary between $A$ 's and $B$ 's land could shift so that although the surface perforation would still be on $A$ 's property, the well would be bottomed on $B$ 's property and $A$ would therefore be liable for trespass and conversion.

49 See, e.g., Champlin Refining Co. v. Aladdin Petroleum Corp., 205 Okla. 524, 238 P.2d 827 (1951).

${ }^{50}$ Under a fixed-boundary rule, fixtures on the surface might seem to become trespassers through the accretion of land along the property boundary. In this situation, however, a developer could be granted an implied easement of access from the surface to the mineral estate below. See infra notes 52-54 and accompanying text.

Another way to protect the rights of subsurface holders, as suggested by the Nilsen court, would be to allow them to make surface modifications to prevent the river from moving. In Nilsen, the court indicated that it would find an implied easement for this purpose. See supra notes 21-22 and accompanying text. Under such an easement, the mineral owner could influence the watercourse by erecting levees, dikes, and other devices to prevent erosion. But the cost of such preventive measures would be enormous where large tracts of land are involved. And whatever the cost, it would be an additional expense that would not be required under a fixed-boundary rule.

Furthermore, these measures could substantially interfere with the surface owner's rights to possess and control the land on the river bank, and possibly with his access to the water as well. See Nilsen, 614 P.2d at 44 (Doolin, J., concurring in part, dissenting in part) ("This, I suggest, makes the surface estate subservient to and burdened with a dominant tenement of an unprecedented nature . . . . Has the mineral owner been afforded species (sic) of private eminent domain?"); Note, Oil and Gas: The Inapplicability of Accretion to Severed Mineral Estates, 34 OKLA. L. REv. 826, 832 (1981) ("Such an infringement upon the rights of the surface owner is both unprecedented and unwarranted."). If such a broad easement is necessary for the fair application of the accretion rule to severed mineral estates, then the rule is stood on its head-as applied to severed mineral estates, the doctrine would allow the subsurface owner substantially to undermine the surface riparian rights that the rule was originally designed to preserve.

${ }^{31}$ Developers might try to negotiate an arrangement with their neighbors under which the neighbors would waive all claims if a dispute subsequently arose. However, any such negotiations would involve costs that would not be incurred under a fixed-boundary rule. 
A different problem arises in the more unusual possibility that a shifting surface boundary would divest the subsurface holder of any access to the original surface estate. The new surface owner then could attempt to destroy the value of the severed mineral estate by refusing to grant access to the surface. If the surface owner could do this, the subsurface holder would no longer be the most productive user. However, the holder of a severed mineral estate is typically granted an implied easement to bring minerals to the surface. ${ }^{52}$ This easement is not merely a private contractual right binding only against the party that granted the severance, but is assumed to be part of the subsurface estate, and "rights implied from the grant are implied by law in all conveyances of the mineral estate. . . absent an express limitation thereon."53 By recognizing the continued enforceability of this easement against the party who takes surface lands under the doctrine of accretion, courts would prevent the disjunction between the estates on and below the surface from affecting the value of the subsurface holding. ${ }^{54}$ Even in these extreme cases, then, the fixed-boundary rule would protect the rights of subsurface holders, who are already in a strong position and have strong incentives to develop the minerals.

3. Reciprocity. A third rationale for applying the doctrine of accretion to surface estates centers on its seemingly evenhanded operation. ${ }^{.5}$ The Supreme Court observed in 1874 that " $\left.t\right]$ he owner takes the chances of injury and of benefit arising from the situation of the property. If there be a gradual loss, he must bear it; if a gradual gain, it is his." ${ }^{56}$ Commentators have criticized this rationale as being circular, since the fact that the risks posed by

${ }^{32}$ See, e.g., Williams v. Gibson, 84 Ala. 228, 231-32, 4 So. 350, 352-53 (1888); Union Producing Co. v. Pittman, 245 Miss. 427, 432-33, 146 So. 2d 553, 555 (1962); Tenneco Oil Co. v. Allen, 515 P.2d 1391, 1396-97 (Okla. 1973); Humble Oil \& Refining Co. v. Williams, 420 S.W.2d 133, 134 (Tex. 1967); see also H. Williams \& C. MeYERs, supra note 15, § 218.

${ }^{53}$ Sun Oil Co. v. Whitaker, 483 S.W.2d 808, 811 (Tex. 1972).

s4 In implying that the subsurface holder has an easement to gain access to the surface, courts often refer to the subsurface estate as the "dominant" estate and to the surface estate as the "servient" estate. See, e.g., id. at 810; id. at 816 (Daniels, J., dissenting). Yet this language may overstate the relations between the surface and subsurface holders. The implied easement is limited in scope to "reasonable use," or use "as is reasonably necessary to effectuate the purposes of the lease." Id. at 810-11; see also id. at 817-22 (Daniels, J., dissenting); H. Williams \& C. MEyers, supra note 15, §§ 218.7, 218.8. In essence, it represents an accommodation between the surface and subsurface holders that will protect the rights of each to the greatest possible extent.

ss See, e.g., Jefferis v. East Omaha Land Co., 134 U.S. 178, 189 (1890); County of St. Clair v. Lovingston, 90 U.S. (23 Wall.) 46, 68-69 (1874); Beck, supra note 12, at 436-37; Note, supra note 5 , at $323-34 \&$ n. 48 .

so Lovingston, 90 U.S. (23 Wall.) at 69. 
accretion may be offset by a potential for gain does not demonstrate that accretion is superior to other rules which would impose different risks or no risks at all. ${ }^{57}$ Thus perhaps this rationale is best understood as stating the negative argument that accretion is no less fair than other possible rules.

The Supreme Court of Oklahoma invoked this reciprocity rationale when it rejected a fixed-boundary rule in Nilsen. The court assumed that where a river separates a severed mineral estate and an unsevered estate, the severed estate could gain land by virtue of accretion, but could not lose it by virtue of erosion. Thus it concluded that a fixed-boundary rule would result in "gross inequities." 188

However, the Oklahoma court misunderstood how a fixedboundary rule would operate. The fixed-boundary rule sets a permanent boundary that remains in place regardless of any shift in the surface boundary owing to accretion. ${ }^{59}$ As such, it does not merely protect against encroachments by neighboring landowners, but also confines the holder of the subsurface rights within the limits of the fixed boundary, with no possibility of expansion. Thus, insofar as subsurface mineral rights are concerned, the rule is perfectly evenhanded-neither side stands to gain or lose. And because the rule of accretion still governs changes in surface boundaries, the equal distribution of gain and loss between surface owners is maintained.

4. Ease of Application. The final and critical factor to be considered is the relative ease with which the two rules can be fol950.

${ }^{37}$ See Beck, supra note 12, at 436-37; Comments on Recent Cases, supra note 12, at

${ }^{58} 614$ P.2d at 42; see supra notes 19-20 and accompanying text.

s9 To illustrate, suppose that a non-navigable river flowing from north to south forms the boundary between an unsevered estate on the eastern bank and a surface estate overlying a severed mineral estate on the western bank. Consider two situations, one in which the river shifts towards the west and another in which the river shifts towards the east. In the first situation, the surface estate on the western bank will be eroded, and the unsevered estate will gain that land on the surface by accretion. However, the boundary between the severed mineral estate and the corresponding subsurface portion of the unsevered estate remains fixed. Thus the surface portion of the unsevered estate will extend farther westward than will the subsurface portion.

In the second situation, the river shifts towards the east. The Nilsen court apparently thought that the unsevered estate would be subject to erosion along its entire western boundary, from the surface to the center of the earth. However, the fixed-boundary rule proposed in this comment would in effect divide the unsevered estate into surface and subsurface portions, corresponding to the division between the surface estate and severed mineral estate on the western bank of the river. Although the surface portion of the unsevered estate would lose land by accretion, the boundary between the subsurface portion and the adjoining severed estate would remain fixed. 
lowed by laymen and applied by courts. The advantages of a fixedboundary rule could evaporate if it is difficult to establish and maintain. For surface lands, some courts have argued that the cost of administering a fixed-boundary rule justifies adoption of the doctrine of accretion. ${ }^{60}$ Similarly, the Jackson court pointed to administrative costs as a reason for rejecting a fixed-boundary rule below the surface.

In particular, the Jackson court observed that under a rule which fixes the boundaries of a severed mineral estate, the surface portion of an unsevered estate can extend beyond the estate's subsurface portion. ${ }^{61}$ Such a discrepancy would arise where there is an unsevered estate on one side of a river and a surface estate overlying a severed mineral estate on the other. If the river moves toward the severed estates, then the unsevered estate's surface portion expands while its subsurface portion remains fixed. Similarly, if the river moves toward the unsevered estate, then the surface of the severed estate expands while the subsurface estate remains fixed.

This discrepancy gives rise to two concerns. First, a fixedboundary rule for subsurface estates may be harder for laymen to apply, since the clear river boundary on the surface no longer demarcates the severed mineral estate. But modern courts have rejected the notion that a river that was once a boundary must always be a boundary. The doctrine of avulsion is a good example. The Romans treated accretive action and avulsive action alike, always preserving the river as a natural boundary. ${ }^{62}$ In contrast, the common law has recognized that the river does not remain the property line when changes in its course are sudden; instead, the boundary stays fixed in accordance with the old riverbed, as identified by survey. ${ }^{63}$ This doctrine undermines the bright-line nature of the river as a boundary, but certainly is more fair to landowners: they risk losing a little here and there to preserve their riparian

so See, e.g., Southern Centre of Theosophy, Inc. v. South Australia, 1982 A.C. 706, 716 (P.C.) ("it is manifestly convenient to continue to regard the boundary between land and water as being where it is from day to day or year to year"); (f. Nebraska v. Iowa, 143 U.S. $359,365-66$ (1892) (quoting Vattel that "nothing is more natural than to take a river for a boundary"); Beck, supra note 12, at 433. But see Comments on Recent Cases, supra note 12, at 949-50 (agreeing that the administrative costs argument is made by courts, but finding it a bad argument).

62 Jackson, 667 P.2d at 409; see supra note 59 and text following note 25.

as See Rudolf Sohm, The Institutes 323 (J. Ledlie trans. 3d ed. 1970); Note, supra note 5 , at $322-23 \&$ n.45 ("The adoption of the de minimus concept set the stage for a legal distinction between gradual and sudden changes along waterways. No such distinction was drawn in Roman law.").

see supra note 7. 
rights, but they do not expect to lose all their land in one day. ${ }^{64}$ Similarly, the fixed boundary of a severed mineral estate is just as easily established by survey, and the rule furthers the important policy of promoting mineral development.

Second, a fixed-boundary rule could create practical problems arising from the disjunction between the surface and subsurface estates. This discrepancy would not be apparent in a search of the chain of title of the unsevered estate. ${ }^{65}$ As a result, a potential purchaser of the unsevered estate would have to take a few more steps in order to identify the extent of his subsurface holdings. The purchaser would have to search the title of the neighboring property to determine whether a mineral estate had been severed. If it had, the potential buyer would have to conduct a survey to establish the relationship between the present surface boundary and the (fixed) subsurface boundary.

Yet these costs are insufficient to justify rejection of a fixedboundary rule. All purchasers will, as a matter of course, search the title of the land they intend to buy; it would require little extra expense to search the title of neighboring property at the same time. And because the doctrine of accretion will continue to apply to surface estates, the purchasers of land abutting a river are likely to conduct surveys anyway to determine the extent to which the surface boundary has changed since the original conveyance of the property. In light of the potential benefits of a fixed-boundary rule, these additional costs do not place an unreasonable burden on purchasers of riparian land.

The Jackson court also identified another potentially more troubling area of concern: a fixed-boundary rule is difficult to apply if no survey was conducted at the time the affected mineral estate was severed. ${ }^{68}$ In such a situation the river might shift hundreds of yards over the course of many decades before a dispute arises about the location of the boundary.

This problem should not arise with severances made after the adoption of a fixed-boundary rule, since landowners and purchasers of mineral estates would be aware of the rule and would conduct surveys at the time of severance. Courts can encourage land-

et Interestingly, in many cases the evidence on whether a shift in a river was accretive or avulsive is not established by whether eyewitnesses could perceive the shift in the river, but by periodic surveys of the riverbed. See, e.g., Ellis v. Union Oil Co. of Cal., 630 P.2d 306, 309 (Okla. 1981).

os Jackson, 667 P.2d at 409.

${ }^{68}$ Id. 
owners to conduct surveys by adopting common law rules that penalize those who fail to do so. Courts might, for example, estop the owner of the severed estate from challenging the location of a surface boundary if the owner had failed to survey within a certain period after severance.

The application of a fixed-boundary rule to severances made before the adoption of the rule poses further but by no means insuperable difficulties. In cases where no survey was conducted at the time of severance, the boundary could be determined by the first survey conducted after the severance. For example, suppose a mineral estate was severed in 1890. A river bounds this estate on one side, and the estate on the other side of this river is unsevered. The river shifted some distance by 1920 , when it was surveyed as part of a periodic government survey of the area. The river shifted even farther by 1985, when a boundary dispute arose. Under the approach suggested here, the boundary between the two estates would be the centerline of the river as established in the 1920 survey. In effect, the doctrine of accretion would apply to boundary changes that occurred before the survey, and a fixed-boundary rule would apply to the changes since that time.

\section{Navigable Rivers}

The previous section has shown that a rule that fixes the boundary of a subsurface mineral estate at the time of severance is preferable to a rule that requires the boundary to move in accord with accretion on the surface. Policy considerations indicate that a fixed-boundary rule would benefit both the parties and the public when the parties share a common boundary consisting of a nonnavigable waterway.

The analysis changes, however, if the boundary river is navigable, because a third party-the state-often holds title to the land beneath navigable rivers. ${ }^{67}$ As the Jackson court suggested, a fixedboundary rule could conflict with this doctrine of state ownership because a shift of a navigable river towards a severed mineral estate could divest the state of its interest in the minerals beneath the riverbed. ${ }^{68}$

This possibility, however, is not substantial enough to over-

67 See, e.g., Driesbach v. Lynch, 71 Idaho 501, 505, 234 P.2d 446, 448 (1951); State v. Raymond, 254 Iowa 828, 831, 119 N.W.2d 135, 137 (1963); Conran v. Girvin, 341 S.W.2d 75, 80 (Mo. 1960). But see, e.g., Hall v. Alford, 114 Mich. 165, 167-68, 72 N.W. 137, 138 (1897); Kinkead v. Turgeon, 74 Neb. 580, 586-88, 109 N.W. 744, 746-47 (1906).

${ }^{8}$ Jackson, 667 P.2d at 408-09. 
come the other advantages of the fixed-boundary rule. To begin with, it is worth noting that the state could be divested of subsurface rights only in very limited circumstances: where a navigable river lies between a severed mineral estate and an unsevered estate, and the river shifts far enough to lie entirely above the severed mineral estate. ${ }^{69}$ This possibility does not arise if neither of the estates bordering the navigable river has severed the mineral rights, nor if both have severed the mineral rights. It also does not arise where the river is shifting toward the unsevered estate. Finally, the state can always fix the boundary of the subsurface estate by severing its mineral rights beneath the riverbed, thus protecting them against encroachments from the adjoining estates on either side of the river.

These scenarios raise a number of points. First, the possibility that the state could be divested of subsurface rights does not show that the fixed-boundary rule treats the state unfairly. This possibility of loss is balanced by an equivalent potential for gain: if the navigable river moves away from a severed estate toward an unsevered estate, the state would gain title to all the subsurface lands traversed by the river (see figure 2). ${ }^{70}$ Thus, the fixed-boundary rule for subsurface estates operates just as the accretion rule does for surface estates: it bestows equal risk of loss and gain, and leaves open the more remote possibility that enough of a shift in the riverbed could strip title to an estate from its current holder altogether. ${ }^{71}$

69 For a description of how this would occur, see supra text following note 26 and figure 2 infra at text following note 71.

${ }^{70}$ To further illustrate how a fixed-boundary rule would operate in the context of navigable rivers, return to the situation in which a river flows from north to south and is slowly shifting eastward. First, assume that the estates on both sides of the river are unsevered. In this situation, the doctrine of accretion would apply.

Second, assume that mineral estates have been severed on both sides of the river. As the river moves eastward, the surface portion of the state's unsevered estate moves eastward to remain coextensive with the river. The western surface estate also gains land by accretion. The subsurface portion of the state's land, however, remains fixed at the original location of the river bed. This occurs because the eastern mineral estate cannot lose land by erosion. The boundary between it and the state's subsurface land therefore remains at the same location.

Finally, assume there is a severed estate on the western bank, and an unsevered estate to the east. As the river moves eastward, both the state's surface and subsurface portions gain land by accretion. The western surface estate gains land by accretion, while the western boundary of the subsurface portion of the state's estate remains fixed. Thus, the state's subsurface estate grows in size as the river moves to the east. This scenario is illustrated in figure 2.

${ }^{71}$ On balance, the state's risk of gain or loss under the fixed-boundary rule is quite favorable. The most the state stands to lose is the subsurface rights beneath the riverbed 
Figure 2: How State Ownership is Affected by Shift of a Navigable Waterway

Before:

\begin{tabular}{|c|c|c|}
\hline \multicolumn{3}{|c|}{$\begin{array}{c}\text { Navigable } \\
\text { River }\end{array}$} \\
\hline $\begin{array}{l}\text { B's surface } \\
\text { estate }\end{array}$ & $\begin{array}{c}\text { State } \\
\text { Riverbed }\end{array}$ & $\begin{array}{l}\text { A's surface } \\
\text { estate }\end{array}$ \\
\hline $\begin{array}{c}\text { severed } \\
\text { mineral } \\
\text { estate }\end{array}$ & $\begin{array}{c}\text { State } \\
\text { subsurface } \\
\text { estate } \\
\text { (unsevered) }\end{array}$ & $\begin{array}{l}\text { A's mineral } \\
\text { estate } \\
\text { (unsevered) }\end{array}$ \\
\hline
\end{tabular}

After (State loses):

New Riverbed

Old

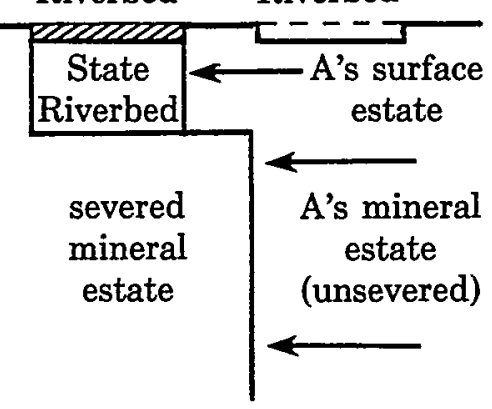

After (State gains):

Old

New

Riverbed

Riverbed

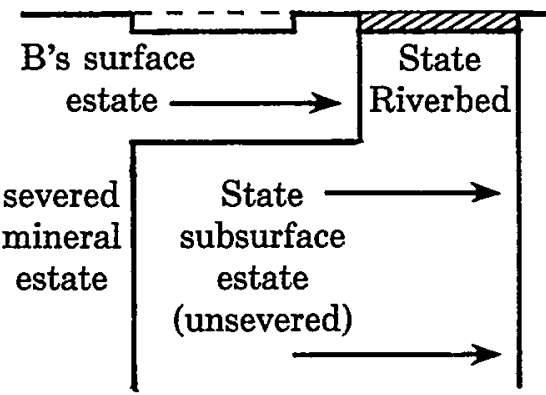

The fixed-boundary rule is not only fair to the state, but may be more advantageous to the state than a simple accretion rule. Under an accretion rule, state subsurface rights are particularly vulnerable. Unlike subsurface rights possessed by riparian estates, the mineral rights beneath a riverbed will be altered if the river moves in either direction. Thus, if the state holds title to valuable subsurface rights below a riverbed, its ability to develop these particular rights on its own or to sell them to some other party is be- 
set by uncertainty. This extra risk reduces the value of the state's rights. In contrast, a fixed-boundary rule allows the state to protect and make certain its subsurface rights. By severing the mineral estate, the state can defend itself against encroachments by adjoining estates, and also can assure that it reaps the bounties of particularly valuable subsurface rights. ${ }^{72}$

Nonetheless, in raising the problem of state ownership, the Jackson court may have been responding to a narrower concern. Quite apart from whether the fixed-boundary rule operates in a manner that is fair to the state, the possibility that the state could be divested of subsurface rights beneath a navigable river may conflict with a statutory mandate that the state hold title to those rights. ${ }^{73}$

This concern seems unwarranted for several reasons. First, the rule that the state owns lands under navigable waterways derives from ancient common law rules ${ }^{74}$ designed to preserve the waters for navigation and to keep the channel clear of obstacles to navigation. ${ }^{75}$ That purpose is adequately served where the state retains a surface estate that is coextensive with the riverbed and shifts with it. Since the only interest the state has in the minerals under the riverbed is proprietary, and has nothing to do with maintaining the river for transportation and commerce, there seems little reason for placing its ownership of those minerals on a footing different from private ownership.

In addition, although some states have codified the rule of state ownership, ${ }^{76}$ it is not obvious why codification should affect the application of the rule. A law that grants ownership of lands beneath navigable rivers to the state allows the state to protect navigational rights of the public at large, and clarifies what might otherwise be a source of dispute. Such a law does not indicate,

72 This point underscores one primary effect of the fixed-boundary rule: it provides an incentive for any holder of an unsevered estate to sever the mineral rights if they are believed to have any significant value.

${ }^{73}$ See Jackson, 667 P.2d at 409.

${ }^{34}$ See Barney v. Keokuk, 94 U.S. 324, 336-39 (1876) (construing Iowa law); Martin v. Waddell, 41 U.S. (16 Pet.) 367, 410 (1842).

${ }^{25}$ See Shively v. Bowlby, 152 U.S. 1, $48-50$ (1894); Barney, 94 U.S. at 337-38; see also Note, supra note 5, at 317-20 (suggesting that in the older English common law the king's title to the beds of navigable waterways was based on "historical peculiarities" having to do with the tidal nature of English waters, but that American common law introduced greater emphasis on the state's role in preserving the navigability of waterways).

${ }^{78}$ See, e.g., MONT. CODE ANN. $\S 70-1-202$ (1985) ("The state is the owner of . . . all land below the water of a navigable lake or stream."); WASH. REv. CODE ANN. $\$ 79.01 .004$ (1962) ("Public lands of the state of Washington ... include . . . the beds of navigable waters belonging to the state."). 
however, that the state holds title to these lands without regard to the common law rules that define the rights to possess, use, and dispose of property. ${ }^{77}$ For example, if the state leased the mineral estate below its riverbed to a private party, the statute would not allow it to break the lease merely on the ground that it has title to those subsurface lands. Furthermore, if the river underwent a sudden avulsive movement, common law doctrines normally would leave the previous boundaries intact, so that the state would keep title to the subsurface lands under the old riverbed and would not hold title to the lands beneath the river's new channel. ${ }^{78}$ Similarly, the existence of a statute should not affect the application of the fixed-boundary rule to severed mineral estates.

Nonetheless, if a court concludes that the statute mandates that it preserve the state's title to the subsurface minerals, it could rule that severance of a mineral estate on either side of the riverbed fixes the subsurface boundaries on both sides of the riverbed. Although this rule would treat state ownership differently from private ownership, it would prevent any possibility of the state losing its subsurface estate. Moreover, as when the state itself severs the minerals, the increased certainty in the state's title will promote the development of the state's mineral estates under navigable rivers.

Two final concerns under a fixed-boundary rule are that the state might come to own a mineral estate that does not lie beneath a navigable waterway, and that the state might fail to own subsurface rights below a navigable waterway. ${ }^{79}$ But these concerns are

${ }^{77}$ One commentator has argued that states hold property rights such as title to waterlands in trust for the public. See Sax, The Public Trust Doctrine in Natural Resource Law: Effective Judicial Intervention, 68 Mrch. L. REv. 471 (1970). However, even this strong "public trust" orientation does not require that the state always hold full title to such lands regardless of common law rules: "The cases stand for the more limited proposition that the state cannot give to private parties such title that those private interests will be empowered to delimit or modify public uses." Id. at 527 . This goal can be achieved if the state retains a surface easement over navigable waterways to protect navigational and other rights enjoyed by the public. See infra note 80 and accompanying text.

78 See Department of Natural Resources v. Mayor \& Council of Ocean City, 274 Md. 1, 15, 332 A.2d 630, 638 (1975) (avulsion does not affect land boundaries and does not give title to the state over lands abruptly flooded); Dickinson v. Fund for the Support of Free Public Schools, 95 N.J. 65, 77, 469 A.2d 1, 7 (1983) ("the State may have no claim to upland that became tidally flooded because of avulsion or some artificially created condition"); In re City of Buffalo, 206 N.Y. 319, 325, 99 N.E. 850, 852 (1912) (an owner's loss of land by avulsion does not return to the ownership of the state, but the boundaries remain where they were before "the sudden or violent action of the elements"); City of Corpus Christi v. Davis, 622 S.W.2d 640, 643-44 (Tex. Ct. App. 1981) (applying arguendo the rule of avulsion to tidal lands held by the state).

70 This would occur whenever the state severed mineral rights beneath a riverbed that 
minor. States may own mineral estates that are not located under rivers, and these subsurface estates are not especially difficult to locate by survey. Moreover, an avulsive movement of a river could produce the same result; even if the river moved a considerable distance, the state's mineral estate would remain fixed in place. The state still would retain as much control over the navigable river as would be necessary to meet its obligation to preserve the river for public navigation. This control would always include the power to improve the watercourse for navigational purposes, even where its projects interfere with private development of mineral estates beneath the river's surface. ${ }^{80}$

\section{ConClusion}

The extraction of minerals is a complex enterprise. Under the doctrine of accretion, the participants in that enterprise are required to make costly readjustments in their contractual relationships and property interests when a boundary shifts. For surface estates, those costs might be worth incurring in order to maintain landowners' access to water or to ensure that accretions are awarded to the party which will make the most productive use of them. However, those justifications are not applicable to mineral rights below the surface. Indeed, the movement of surface waters is essentially irrelevant to a rational system of subsurface ownership rights.

Instead, analysis of several factors indicates that adoption of a fixed-boundary rule for severed mineral estates is the better alternative. Under this rule, the doctrine of accretion would continue to govern changes in boundaries between surface estates or unsevered mineral estates. However, once a mineral estate is severed from the surface estate, its boundary would be fixed regardless of future changes in surface boundaries. Although, as two state courts have

later shifted away from its original channel. It could also occur if the state's subsurface estate were fixed in place by the severance of contiguous mineral estates.

${ }^{80}$ See, e.g., State v. Superior Court ex rel. Lyon, 29 Cal. 3d 210, 226-32, 172 Cal. Rptr. $696,705-09,625$ P.2d 239, 248-52 (recognizing that private ownership of lake property between the high-water and low-water marks is "impressed with the public trust," which allows the public to make various uses of the waters and lands, and allows the owner to make any use of the lands "not incompatible with the public's interest in the property"), cert. denied, 454 U.S. 865 (1981); cf. United States v. Chandler-Dunbar Water Power Co., 229 U.S. 53, 62, 70 (1913) (ownership of bank or bed of river is subordinate to the public right of navigation). 
correctly recognized, there are some practical difficulties in the application of a fixed-boundary rule, in the long run those problems are outweighed by the rule's advantages.

Robert L. Kimball 